\title{
Analysis of interactions among barriers in project risk management
}

\author{
Rahul V. Dandage ${ }^{1} \cdot$ Shankar S. Mantha ${ }^{2} \cdot$ Santosh B. Rane $^{1} \cdot$ Vanita Bhoola $^{3}$
}

Received: 16 July 2016/ Accepted: 14 June 2017 / Published online: 26 June 2017

(c) The Author(s) 2017. This article is an open access publication

\begin{abstract}
In the context of the scope, time, cost, and quality constraints, failure is not uncommon in project management. While small projects have $70 \%$ chances of success, large projects virtually have no chance of meeting the quadruple constraints. While there is no dearth of research on project risk management, the manifestation of barriers to project risk management is a less dwelt topic. The success of project management is oftentimes based on the understanding of barriers to effective risk management, application of appropriate risk management methodology, proactive leadership to avoid barriers, workers' attitude, adequate resources, organizational culture, and involvement of top management. This paper represents various risk categories and barriers to risk management in domestic and international projects through literature survey and feedback from project professionals. After analysing the various modelling methods used in project risk management literature, interpretive structural modelling (ISM) and MICMAC analysis have been used to analyse interactions among the barriers and prioritize them. The analysis indicates that lack of top management support, lack of formal training, and lack of addressing cultural differences are the high priority barriers, among many others.
\end{abstract}

Rahul V. Dandage

dandagerahul@gmail.com

1 Mechanical Engineering Department, Sardar Patel College of Engineering, Mumbai, India

2 All India Council for Technical Education (AICTE), New Delhi, India

3 SP Jain Institute of Management and Research, Mumbai, India
Keywords Projects · Risk management - Barriers · ISM · MICMAC

\section{Introduction}

A project is defined as a series of related activities with a well-defined set of desired end results (Fan et al. 2008). Projects are temporary organizational forms with unique features that set them apart from permanent organizational forms (Palm and Lindahl 2015). Walewski and Gibson (2003) defines international projects as those where owner or contractor of the projects are from a different country than the one, where the project is being executed. International projects are classified by Grey et al. (2010) as overseas (executed in a foreign country for a native firm), foreign (executed in a foreign country for a foreign firm), or global (project team consisting of professionals from multiple countries) projects. Han et al. (2008) claimed that overseas projects tend to have a high possibility of loss/failure compared to domestic projects.

In project management, high levels of risk are considered to be a significant obstacle for project success (Zwikael and Sadeh 2007). Zwikael et al. (2013) defined risk as a scenario in which a project suffers a damaging effect. Projects are often exposed and averse to risks, and stakeholders ask for risk management to cover themselves against financial or legal consequences (Fang and Marle 2012). Hence, risk management becomes an integral part of project management (Isaac 1995; Han et al. 2008; Elkington and Smallman 2002). Risk management is very crucial for any project to complete successfully without compromising on the quadruple constraints of scope, cost, schedule, and quality (Yazid et al. 2014). Miller and Lessard (2001) proposed that understanding and managing 
project risks in large engineering projects are challenging tasks at the early phase. International projects have high levels of risk and complexity, which result in greater possibilities of overrun and conflict when compared with domestic projects (Eybpoosh et al. 2011).

A survey conducted by Standish Group International Inc. (The Standish group CHAOS report 2013) shows that only $25-30 \%$ projects are completed successfully. Most of the projects fail due to cost overrun or schedule overrun. Success of any project mainly depends on upon understanding the risks associated with the specific project and effective implementation of risk management (Walewski and Gibson 2003). Tah and Carr (2001) emphasized the importance of establishing a systematic risk management process for each decision phase of a construction project. Effective project risk management is possible by knowing the various barriers in risk management and the strategies to overcome them (Hwang et al. 2014; Harner 2010).

Some risks remain constant throughout project, whereas some risks arise and diminish during the project (PMI 2013). To improve project performance, the risks which occur across entire project life cycle must be recognized and managed.

\section{Literature survey}

\section{Risks involved in projects}

Risk is a triple characteristic of any project decision in the situation of uncertainty. It can be defined as a trinity of risk event $(A)$, risk probability $(P)$, and function of risk losses (u) (Titarenko 1997). According to PMBOK (2013), risk is often referred to as the presence of potential or actual threats or opportunities that have an influence on the objective of the project during construction, commissioning or at the time of use. Risk is also defined as an uncertain event or condition that, if it occurs, has a positive or negative effect on the project objectives. Jannadi and Almishari (2003) defined risk as the potential damage that may affect personnel or property. Sato and Hirao (2013) defined risk as the possibility of a critical situation, where an activity cannot deliver mandatory outcomes required for the project objectives and no other immediate alternatives are available. Ward and Chapman (2003) proposed the term uncertainty instead of risk to indicate that it may be a threat or opportunity as well.

The less predictable nature of projects makes them riskier than routine business activities (Elkington and Smallman 2002). All project lifecycles consist of a sequence of stages and activities, from origin to completion and there is always a degree of risk associated with each stage (Stewart and Fortune 1995). The organizational and technological complexity of projects can generate enormous risks (Marle and Vidal 2011; Aloini et al. 2012; Zou et al. 2007; Carr and Tah 2001). Managing risks in every phase is very important to improve project success rates (Bush et al. 2005; Keizer et al. 2002; Smith and Merritt 2002).

As stated by Latham (1994), risk can be managed, minimized, shared, transferred, or accepted, but cannot be ignored. As elaborated by Sarewitz et al. (2003), the two components of risk are event risk and outcome risk. Event risk is the occurrence of a particular event, whereas outcome risk is the particular outcome.

Risk management is one of the key project management processes (Raz and Michael 2001). In general, the risk management is a vital, an on-going and iterative process use to identify possible risks sources during different phases of projects under development (Boateng et al. 2015). Aven (2016) stated that the concept of risk and risk assessments has a long history, but risk assessment and management was established as a scientific field some 30-40 years ago. Most of the research on risk management has focused on risk identification and analysis (Kirkire et al. 2015). The information which is generated through the use of project risk management is applied within the project (Patterson and Neailey 2002). The main purpose of project risk management is to identify, evaluate, and control the risks for project success (Lee et al. 2009). Risk management can help project managers to anticipate delays that cause projects not to be delivered on time (Grant et al. 2006). The risks must be identified before they become problems. Elkington and Smallman (2002) mentioned risk identification as the most important stage of risk analysis as no work can be done on risks that no one has discovered. Risk identification and the development of implementation of risk management strategies must be carried out throughout the life of a project (Stewart and Fortune 1995; Turner et al. 2010). Earlier studies (Murray et al. 2011) put forth that various techniques such as brainstorming, Delphi technique, interviews, surveys, scenario analysis, work breakdown structure analysis, checklist, questionnaire, fault tree analysis, etc. are commonly used for identifying project risks. Based on studies by various researchers, risks involved in projects can be broadly generalized, as mentioned in Table 1.

\section{Barriers in project risk management}

While there is no dearth of research on project risk management, the manifestation of barriers to project risk management is a less dwelt topic (Kutsch and Hall 2010). Failure to identify and eliminate the barriers for risk management affects the risk management practices and leads to project failure. Failed projects have many 
Table 1 Summary of risk categories

\begin{tabular}{|c|c|c|c|}
\hline Sr. no. & Risk category & Key risk causes & Authors \\
\hline 1 & Financial and economical & $\begin{array}{l}\text { (i) Exchange rate fluctuation } \\
\text { (ii) Shortage of funds }\end{array}$ & $\begin{array}{l}\text { Ahsan and Gunawan (2010); Hartono et al. (2013), } \\
\text { Hwang et al. (2013); Lam et al. (2007); Gupta and } \\
\text { Sravat (1998) }\end{array}$ \\
\hline 2 & Contractual and legal & $\begin{array}{l}\text { (i) Unawareness of legal procedures } \\
\text { (ii) Complex contract conditions }\end{array}$ & $\begin{array}{l}\text { Charoenngam and Yeh (1999); Hartono et al. (2013), } \\
\text { Hwang et al. (2013); Jamil et al. (2008); Lam et al. } \\
\text { (2007); Shuying (2009) }\end{array}$ \\
\hline 3 & Subcontractor & Failure of contractor & Lam et al. (2007) \\
\hline 4 & Operational & Low labour and equipment productivity & $\begin{array}{l}\text { Anderson (2000); Eybpoosh et al. (2011); Ghosh and } \\
\text { Jintanapakanont (2004); Ke et al. (2010); Gupta and } \\
\text { Sravat (1998) }\end{array}$ \\
\hline 5 & Safety and social & $\begin{array}{l}\text { (i) Lack of safety training } \\
\text { (ii) Nonstandard working conditions }\end{array}$ & $\begin{array}{l}\text { Anderson (2000); Bing et al. (2005); Hwang et al. } \\
\text { (2013) }\end{array}$ \\
\hline 6 & Design & $\begin{array}{l}\text { (i) Unclear specifications } \\
\text { (ii) Unfamiliarity with standards and codes }\end{array}$ & Hartono et al. (2013), Hwang et al. (2013) \\
\hline 7 & Physical & Unforeseen site conditions & $\begin{array}{l}\text { Doloi et al. (2012); Ghosh and Jintanapakanont (2004); } \\
\text { Lam et al. (2007) }\end{array}$ \\
\hline 8 & Delay & $\begin{array}{l}\text { (i) Legal procedures } \\
\text { (ii) Inadequate resources }\end{array}$ & Hartono et al. (2013), Hwang et al. (2013) \\
\hline 9 & Political & $\begin{array}{l}\text { (i) Political instability } \\
\text { (ii) Relations with government }\end{array}$ & $\begin{array}{l}\text { Charoenngam, and Yeh (1999); Hartono et al. (2013), } \\
\text { Hwang et al. (2013); Jamil et al. (2008); Ke et al. } \\
\text { (2010); Khattab et al. (Khattab et al. 2007); Lam et al. } \\
\text { (2007); Shuying (2009) }\end{array}$ \\
\hline 10 & Internally generated & $\begin{array}{l}\text { (i) Human behaviour } \\
\text { (ii) Failure of project manager }\end{array}$ & Barber (2005) \\
\hline 11 & Cultural & $\begin{array}{l}\text { (i) Language barrier } \\
\text { (ii) Differences in cultures }\end{array}$ & Eybpoosh et al. (2011); Jamil et al. (2008) \\
\hline 12 & Technical & $\begin{array}{l}\text { (i) Variation in codes and standards } \\
\text { (ii) Failure of equipment }\end{array}$ & Doloi et al. (2012) \\
\hline 13 & Level of competition & $\begin{array}{l}\text { (i) No. of competitors } \\
\text { (ii) Tight profit margins }\end{array}$ & Ahsan and Gunawan (2010) \\
\hline 14 & Fraudulent practices & Corruption & Hwang et al. (2013) \\
\hline 15 & Managerial & $\begin{array}{l}\text { (i) Strikes } \\
\text { (ii) Retention of competent staff }\end{array}$ & Camprieu (2007); Sennara and Hartman (2002) \\
\hline 16 & Health related & Low life expectancy age & Anderson (2000); Ling and Hoi (2006) \\
\hline 17 & Force majeure & Natural disasters & Hwang et al. (2013); Ke et al. (2010) \\
\hline
\end{tabular}

consequences, including financial losses, negative press, loss of customer trust, and loss of competitive advantage. There exists a strong need for research that improves project success (Yim et al. 2015). Some common barriers to effective risk management as put forth in the literature in domestic or international projects are explained in this section. The barriers vary as per the circumstances and may exist with any typical combination.

(i) Inertia of employees (Resistance to change): Lundy and Morin (2013) state that how resistance to change or employees' inertia is one of the frequently encountered barriers for effective project risk management and leadership. As stated by Tummala et al. (1997), primary reasons for resistance are often lack of clarity and uncertainty of change, pressure, interference with interests, and reluctance to learn something new and hence managing resistance to change.

(ii) Avoidance of talking about risk: Bhoola et al. (2014) mention that poor communication between top management and project team leads to risk avoidance, due to fear of transferring bad news. Individuals highlight only benefits and downplay risks to secure their positions in the project team by sounding more enthusiastic and positive. Liu et al. (2015) argue that blocking the communication 
channels and discussion on risk implications can defeat the purpose of risk management and informed decision making.

(iii) High cost of risk management: Allen et al. (2015) discuss the impact of risk management on cost management of projects. Project cost management can include planning estimating budgeting, financing, funding, and other forms of controlling costs, as well. Even risk mitigation strategies often require more budgets which may push project cash flows toward a negative side (Sato and Hirao 2013).

(iv) Lack of top management support: Liu et al. (2015) argue that the major factor responsible for IT project failures is lack of top management. The authors suggest that repeated interactions with top management and gaining their confidence can often facilitate social capital and avert project failure. On the contrary, the absence of committed leadership along with lack of strategic direction toward implementation of risk management is an important barrier to effective risk management for projects.

(v) Lack of formal training to employees: Tummala et al. (1997) highlighted the importance of training on risk management practices. Lack of formal training of employees in the area of concepts and principles of project risk management can become a stumbling block in the implementation of risk management methodologies. Hanna et al. (2016) argue that training is an enabler in better competency matching. The paper suggests that project managers should focus on developing their cognitive skills rather than working in a process-driven setup.

(vi) Cultural difference: Jamil et al. (2008) opine that international projects are difficult to manage and complicated as they involve stakeholders from different cultures. Such cultural differences can cause serious concern for effective risk management. According to Harner (2010), there is a strong link between corporate culture and risk management practices. Cultural differences bring mismatch in strategic thinking which becomes a roadblock to effective implementation of risk management.

(viii) Lack of cooperation between employee and top management: according to Liu et al. (2015), strong cooperation and mutual trust between employees and top management is a prerequisite for creating an atmosphere for effective implementation of risk management. Top management must delegate authorities, increase decision-making culture amongst employees, and pay heed to their suggestions which will help in building mutual trust in the organization.

(viii) Cross-functional conflicts: any project consists of a large number of functions, and hence, employees are divided into many functional departments. Huo et al. (2016) discuss a set of antecedents to relationship conflicts in cross-functional projects or projects with several functions. The authors argue that relationship conflicts are universal phenomena in multi-functional projects. The authors further opine that relationship conflicts are often triggered by intrapersonal diversity, project uncertainty, culture diversity, and behavioural expectations from team members.

(ix) Lack of resources: Farr-Wharton (2003) suggests that insufficient resources can result in project failure, despite all the endeavour of the team. The lack of resources such as funds, people, and technology can be a barrier to successful implementation of risk management in any project. Hwang et al. (2014) argue lack of budget as one of the prominent barriers to extract the benefits of risk management in small projects.

(x) Failure to clearly define risks: Bhoola et al. (2014) stress on the significance of risk identification. The authors divide risks into four categories-avoidance, transference, mitigation, and acceptance-and discuss the impact of each on project success. Vaisblat (2014) discusses the need for clarity in defining risks precisely and proposes a system of project risk indicators.

\section{Interpretive structural modelling (ISM)}

At this backdrop of the multiplicity of barriers to implementing effective risk management practices in project management, it would be interesting to look at tools that permit identification of structure within such barriers within a system. Warfield (1974) theoretically developed an interpretive structural model (ISM). ISM is a systematic application of some elementary graph theory in such a way that theoretical, conceptual, and computational advantages are exploited to explain complex pattern of conceptual 
relations among variables (Shahabadkar et al. 2012). ISM uses words, digraphs, and discrete mathematics to reveal the intrinsic structure of system/complex issues/problem under consideration (Jadhav et al. 2015a, b). ISM has been used by researchers for understanding direct and indirect relationships among various variables in different industries (Jadhav et al. 2014b, 2015a). ISM is a tool which permits identification of structure within a system (Jadhav et al. 2014a; Kumar et al. 2013a, b; Raj et al. 2010; Rajesh et al. 2007; Solanki and Choudhary 2014). ISM is used for identifying and summarizing the relationship amongst the variables related to an issue or problem by developing a well-defined model (Alawamleh and Popplewell 2011; Attri et al. 2013; Charan et al. 2008; Eswarlal et al. 2011; Faisal 2010; George and Pramod 2014; Kannan et al. 2008; Ravi and Shankar 2005). Thakkar et al. (2008) compared three contemporary modelling techniques: analytic hierarchy process (AHP), analytic network process (ANP), and interpretive structural modelling (ISM) and found that ISM has a higher capability to capture dynamic complexity. Hence, in this study, we would use the ISM model.

\section{Problem definition}

The literature survey resulted in certain research gaps. Research in the area of exploring barriers to effective project risk management is scanty. The authors failed to identify any research that prioritizes barriers for implementing project risk management using the ISM or any other similar model.

This paper aims to generate a general list of barriers to project risk management by referring the various barriers identified in the literature, analyse the interaction among the barriers for risk management, develop the interpretive structural model for prioritization of barriers affecting risk management in projects, and suggest strategies for overcoming such barriers.

\section{Methodology}

\section{Research objective}

To sustain competition, organizations are expanding their businesses into new and uncharted markets by undertaking domestic as well as international projects. It is essential for companies to understand the risks involved with projects and their impact on sustained competitiveness and growth in global markets. Project risk management is a systematic process of identifying, analysing, and responding to project risks. Project risk management can be effective if the barriers to risk management are identified and tackled effectively (Han et al. 2008).
Based on extensive literature review, the paper identifies various barriers in project risk management and explores the possibility of applying the interpretive structural model (ISM) and MICMAC analysis to identify and summarise the relationship among risk barriers and their relative significance.

\section{Research methodology}

The study is exploratory in nature and uses the literature as a secondary source of data. Using the vast literature that exists in the field of project management and risk management in projects, the following criteria were used for selecting literature:

- Literature published on project management, risks and barriers in risk management, and ISM methodology between 1995 and 2015.

- Frequency of citation between 1995 and 2015 published in journals with a source normalized impact per paper (SNIP) higher than 2.0 (Moed 2010).

- Papers considered for the study included the literature available with virtual libraries, limited to Elsevier (Science Direct), EBSCO and Emerald.

Primary and secondary keywords such as "project risk management", "barriers", "project success", "project failure", "project challenges", and a combination of these were used for preparing a repertoire for the study. The references of the recent research papers were also linked to previous work done by the same authors in project risk management, as well (see Fig. 1).

\section{Procedure of ISM}

ISM is a modelling technique in which the specific relationships among the variables and the overall structure of the system under consideration are portrayed in a digraph model. The various steps involved in the ISM methodology are as follows (Ravi and Shankar 2005):

Step 1: Variables affecting the system under consideration can be objectives, actions, individuals, etc. In this case, the variables are barriers to risk management in projects.

Step 2: From the variables identified in Step 1, a contextual relationship is established among variables with respect to which pairs of variables would be examined.

Step 3: A structural self-interaction matrix (SSIM) is developed for variables, which indicates pairwise relationships among variables of the system under consideration.

Step 4: Initial reachability matrix is developed from the SSIM and the matrix is checked 
Fig. 1 Research methodology flowchart

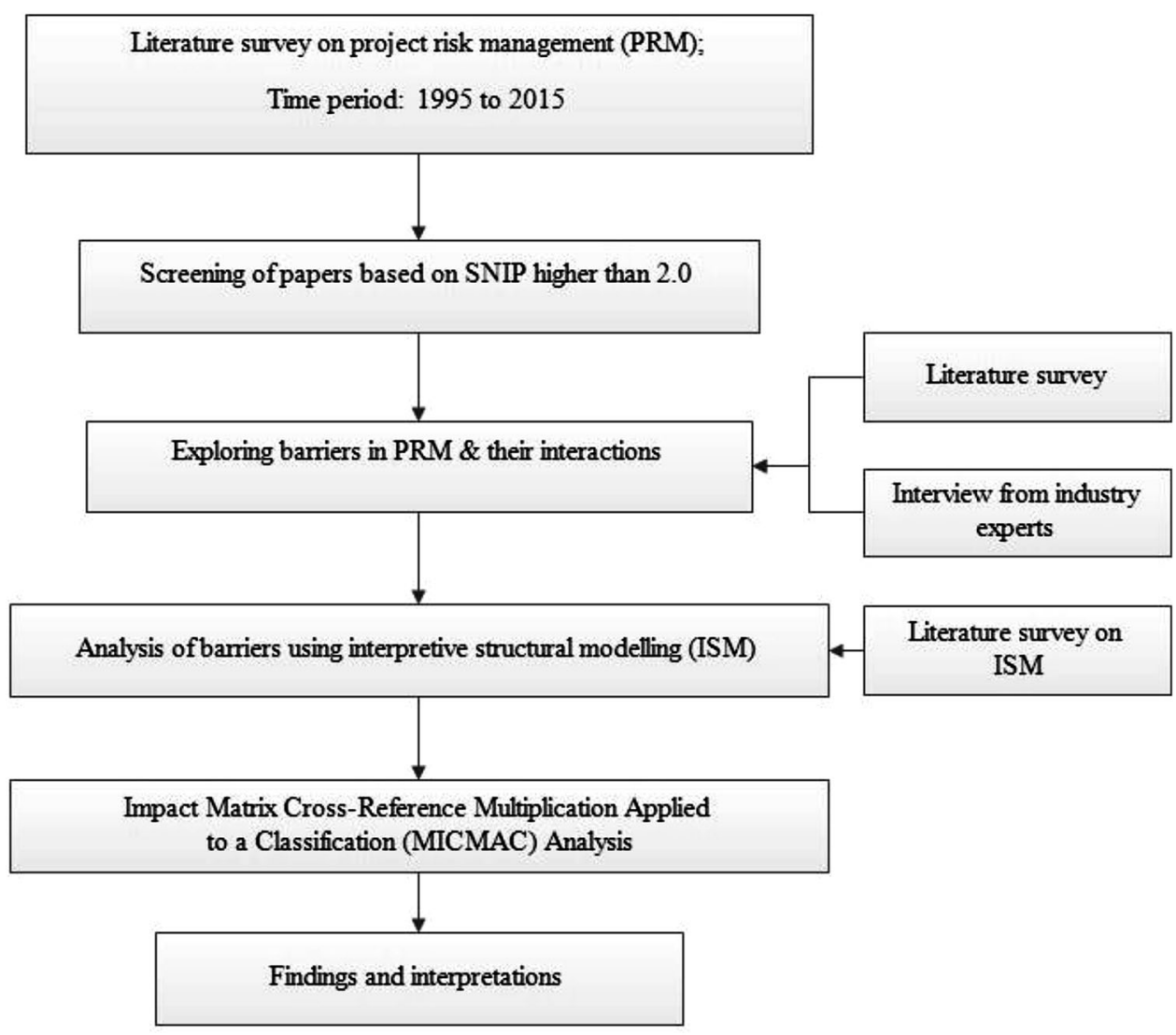

for transitivity. Transitivity of the contextual relation is a basic assumption made in ISM. It states that if a variable $\mathrm{A}$ is related to $\mathrm{B}$ and $\mathrm{B}$ is related to $\mathrm{C}$, then $\mathrm{A}$ is necessarily related to $\mathrm{C}$. This transitivity is reflected in the final reachability matrix.

Step 5: The reachability matrix obtained in Step 4 is partitioned into different levels.

Step 6: Based on the relationships given above in the reachability matrix, a directed graph is drawn and the transitive links are removed.

Step 7: The resultant digraph is converted into an ISM, by replacing variable nodes with statements.

Step 8: The ISM model developed in Step 7 is reviewed to check for conceptual inconsistency and necessary modifications are made.

These steps of ISM modelling are illustrated in Fig. 2.

\section{Development of structural self-interaction matrix (SSIM)}

Ten barriers were identified from literature review and expert opinion. More than 20 industry professionals were consulted to confirm the various barriers to risk management, as represented in the literature.

"Leads to" or "influences" type of contextual relationship is chosen for analysing barriers of risk management. It indicates that a particular barrier influences another barrier. Considering this as a basis, the contextual relationship amongst barriers is developed.

The following four symbols were used to denote direction of relationship between the barriers $(i$ and $j$ ):

$V$ : barrier i influences barrier $j$.

$A$ : barrier $\mathrm{i}$ is influenced by barrier $j$.

$X$ : barrier $i$ and $j$ influence each other.

$O$ : barrier $i$ and $j$ do not influence each other, since they are unrelated.

The contextual relationship among barriers to risk management was identified in consultation with five industry experts having more than 10 years of experience in the project risk management area. Using their expertise, the SSIM was developed, as represented in Table 2.

As observed in Table 2, in most cases, either one barrier influences the other, as denoted by symbols "V" and "A". For example, the symbol "A" connecting "inertia of employees" and "10" implies that the former gets influenced by "failure to clearly define the risk". Similarly, the symbol "V" connecting "inertia of employees and " 8 " 
Fig. 2 Flowchart for developing a model using ISM

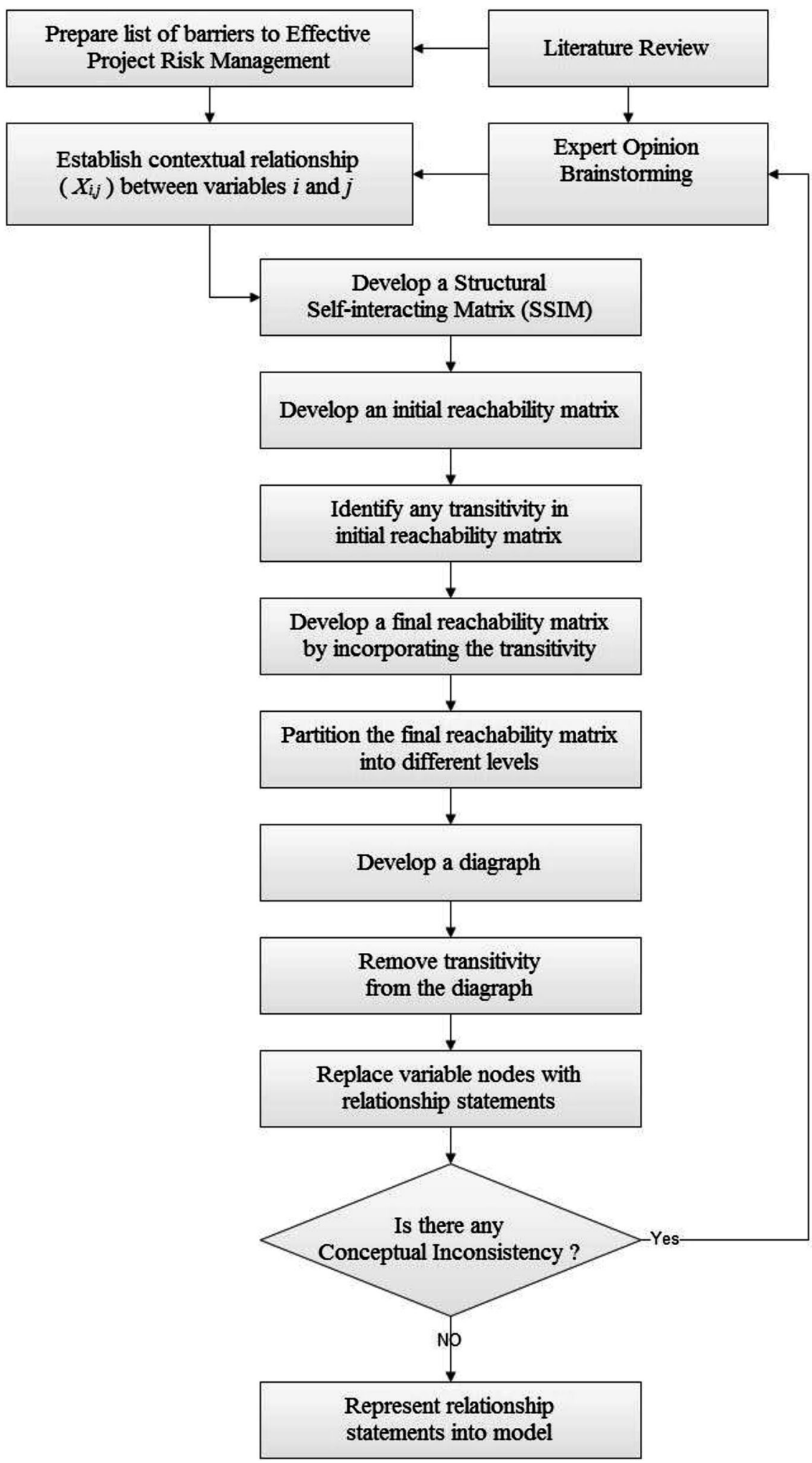

implies that the former influences the barrier "cross-functional conflicts". There are three cases indicated by symbol "O", where there is no relationship, and there is one case indicated by symbol " $\mathrm{X}$ ", where there is mutual interdependence.
Development of initial reachability matrix

The initial reachability matrix is obtained from SSIM by transforming information of each cell of SSIM into binary digits (i.e., 1 or 0 ). This transformation has been done by 
Table 2 Structural selfinteraction matrix (SSIM)

\begin{tabular}{llllllllll}
\hline Barriers $(i \downarrow ; j \rightarrow)$ & 10 & 9 & 8 & 7 & 6 & 5 & 4 & 3 & 2 \\
\hline 1. Inertia of employees & A & A & V & A & A & A & A & A & V \\
2. Avoidance of talking about risk & V & A & A & A & A & A & A & A & \\
3. High cost of risk management & A & V & A & A & O & A & A & & \\
4. Lack of top management Support & V & V & V & V & V & V & & & \\
5. Lack of formal training to employees & V & A & V & O & V & & & & \\
6. Cultural difference & V & O & V & V & & & & & \\
7. Lack of cooperation between employee and top managements & V & V & X & & & & & & \\
8. Cross-functional conflicts & A & A & & & & & & & \\
9. Lack of resources & A & & & & & & & & \\
10. Failure to clearly define the risk & & & & & & & & \\
\hline
\end{tabular}

Table 3 Transformation rules

\begin{tabular}{lll}
\hline If the $(i, j)$ entry in the SSIM is & \multicolumn{2}{l}{ Entry in initial reachability matrix } \\
\cline { 2 - 3 } & $(i, j)$ & $(j, i)$ \\
\hline $\mathrm{V}$ & 1 & 0 \\
$\mathrm{~A}$ & 0 & 1 \\
$\mathrm{X}$ & 1 & 1 \\
$\mathrm{O}$ & 0 & 0
\end{tabular}

substituting $\mathrm{V}, \mathrm{A}, \mathrm{X}, \mathrm{O}$ by 1 and 0 as per the following rules. Rules for transformation are given in Table 3.

Therefore, we assign " 1 " corresponding to " $\mathrm{V}$ " if barrier " $i$ " influences barrier " $j$ " and " 0 " otherwise. If barrier " $j$ " influences " $i$ ", it is captured by "A". If there is mutual interdependence, then both the entries are assigned " 1 " and " 0 " if there is no relationship.

Following above rules of transformation, initial reachability matrix is developed, as shown in Table 4.

Capturing the relationship among the barriers in the form of binary numbers, Table 4 is generated. In the cases of "V" and "A", the relationships follow one way. However, in the case of barriers " 7 " and " 8 ", for example, it is " 1 " both ways. Similarly, in the case of barriers "6" and "9", it is "0" both ways.

\section{Development of final reachability matrix}

To get final reachability matrix, the concept of transitivity is introduced, and some of the cells of initial reachability matrix are filled by inference. If a variable ' $i$ ' is related to ' $j$ ' and ' $j$ ' is related to ' $k$ ', then transitivity implies that variable ' $i$ ' is necessarily related to ' $k$ '. The final reachability matrix is developed after incorporating transitivity concept and is represented in Table 5.

The number of drivers is captured by the horizontal summation of the rows. The vertical summation of the rows is called "dependence". As observed from this table, "lack of top management support has the lowest dependence value and the highest driver value. This implies that top management support is a significant driver to all other barriers; however, it is not true, the other way.

\section{Level partitioning the final reachability matrix}

The reachability set and antecedent set for each barrier are established from final reachability matrix. The reachability set for a particular barrier consists of the barrier itself and the other barriers, which it influences, whereas the antecedent set consists of the barrier itself and other barriers which may influence it. Subsequently, the intersection of
Table 4 Initial reachability matrix

\begin{tabular}{lllllllllll}
\hline Barriers & 1 & 2 & 3 & 4 & 5 & 6 & 7 & 8 & 9 & 10 \\
\hline 1. Inertia of employees & 1 & 1 & 0 & 0 & 0 & 0 & 0 & 1 & 0 & 0 \\
2. Avoidance of talking about risk & 0 & 1 & 0 & 0 & 0 & 0 & 0 & 0 & 0 & 1 \\
3. High cost of risk management & 1 & 1 & 1 & 0 & 0 & 0 & 0 & 0 & 1 & 0 \\
4. Lack of top management support & 1 & 1 & 1 & 1 & 1 & 1 & 1 & 1 & 1 & 1 \\
5. Lack of formal training to employees & 1 & 1 & 1 & 0 & 1 & 1 & 0 & 1 & 0 & 1 \\
6. Cultural difference & 1 & 1 & 0 & 0 & 0 & 1 & 1 & 1 & 0 & 1 \\
7. Lack of cooperation between employee and top management & 1 & 1 & 1 & 0 & 0 & 0 & 1 & 1 & 1 & 1 \\
8. Cross-functional conflicts & 0 & 1 & 1 & 0 & 0 & 0 & 1 & 1 & 0 & 0 \\
9. Lack of resources & 1 & 1 & 0 & 0 & 1 & 0 & 0 & 1 & 1 & 0 \\
10. Failure to clearly define the risk & 1 & 0 & 1 & 0 & 0 & 0 & 0 & 1 & 1 & 1 \\
\hline
\end{tabular}


Table 5 Final reachability matrix

\begin{tabular}{|c|c|c|c|c|c|c|c|c|c|c|c|}
\hline Barriers & 1 & 2 & 3 & 4 & 5 & 6 & 7 & 8 & 9 & 10 & Driver \\
\hline 1. Inertia of employees & 1 & 1 & $1 *$ & 0 & 0 & 0 & $1 *$ & 1 & 0 & $1^{*}$ & 06 \\
\hline 2. Avoidance of talking about risk & $1^{*}$ & 1 & $1^{*}$ & 0 & 0 & 0 & 0 & $1^{*}$ & $1^{*}$ & 1 & 06 \\
\hline 3. High cost of risk management & 1 & 1 & 1 & 0 & $1^{*}$ & 0 & 0 & $1^{*}$ & 1 & $1^{*}$ & 07 \\
\hline 4. Lack of top management support & 1 & 1 & 1 & 1 & 1 & 1 & 1 & 1 & 1 & 1 & 10 \\
\hline 5. Lack of formal training to employees & 1 & 1 & 1 & 0 & 1 & 1 & $1^{*}$ & 1 & $1 *$ & 1 & 09 \\
\hline 6. Cultural difference & 1 & 1 & $1^{*}$ & 0 & 0 & 1 & 1 & 1 & $1^{*}$ & 1 & 08 \\
\hline 7. Lack of cooperation between employee and top management & 1 & 1 & 1 & 0 & $1^{*}$ & 0 & 1 & 1 & 1 & 1 & 08 \\
\hline 8. Cross-functional conflicts & $1 *$ & 1 & 1 & 0 & 0 & 0 & 1 & 1 & $1^{*}$ & $1^{*}$ & 07 \\
\hline 9. Lack of resources & 1 & 1 & $1^{*}$ & 0 & 1 & $1 *$ & $1^{*}$ & 1 & 1 & $1^{*}$ & 09 \\
\hline 10. Failure to clearly define the risk & 1 & $1^{*}$ & 1 & 0 & $1 *$ & 0 & $1^{*}$ & 1 & 1 & 1 & 08 \\
\hline Dependence & 10 & 10 & 10 & 01 & 06 & 04 & 08 & 10 & 09 & 10 & \\
\hline
\end{tabular}

*Represents transitivity in relationship

reachability and antecedent is derived for all barriers and levels of different barriers are determined.

The barriers for which reachability sets and intersection sets are identical, assigned top level in the ISM hierarchy. Top-level barriers are those that will not lead the other barriers above their own level in the hierarchy. Once the top-level barrier is identified, it is discarded from the further hierarchical analysis. This iteration is repeated until the levels of each barrier are found out (Tables 6, 7, 8, 9,
10, 11, 12, 13). Level identification process of these barriers is completed in eight iterations.

The first iteration considers all the ten barriers for their reachability and antecedent sets. Since the intersection set and reachability set of the tenth barrier are identical and contain a maximum number of common barriers, the barrier "failure to clearly define risk" is selected at the top level (ref. Table 6).

Table 6 Level partition-Iteration I

\begin{tabular}{llll}
\hline Barriers & Reachability set & Antecedent set & Intersection set \\
\hline 1. Inertia of employees & $1,2,3,7,8,10$ & $1,2,3,4,5,6,7,8,9,10$ & $1,2,3,7,8,10$ \\
2. Avoidance of talking about risk & $1,2,3,8,9,10$ & $1,2,3,4,5,6,7,8,9,10$ & $1,2,3,8,9,10$ \\
3. High cost of risk management & $1,2,3,5,8,9,10$ & $1,2,3,4,5,6,7,8,9,10$ & $1,2,3,5,8,9,10$ \\
4. Lack of top management support & $1,2,3,4,5,6,7,8,9,10$ & 4 & 4 \\
5. Lack of formal training to employees & $1,2,3,5,6,7,8,9,10$ & $3,4,5,7,9,10$ & $3,5,7,9,10$ \\
6. Cultural difference & $1,2,3,6,7,8,9,10$ & $4,5,6,9$ & 6,9 \\
7. Lack of cooperation between employee and top management & $1,2,3,5,7,8,9,10$ & $1,4,5,6,7,8,9,10$ & $1,5,7,8,9,10$ \\
8. Cross-functional conflicts & $1,2,3,7,8,9,10$ & $1,2,3,4,5,6,7,8,9,10$ & $1,2,3,7,8,9,10$ \\
9. Lack of resources & $1,2,3,5,6,7,8,9,10$ & $2,3,4,5,6,7,8,9,10$ & $2,3,5,6,7,8,9,10$ \\
10. Failure to clearly define the risk & $1,2,3,5,7,8,9,10$ & $1,2,3,4,5,6,7,8,9,10$ & $1,2,3,5,7,8,9,10$ \\
\hline
\end{tabular}

Table 7 Level partition-Iteration II

\begin{tabular}{llll}
\hline Barriers & Reachability set & Antecedent set & Intersection set \\
\hline 1. Inertia of employees & $1,2,3,7,8$ & $1,2,3,4,5,6,7,8,9$ & $1,2,3,7,8$ \\
2. Avoidance of talking about risk & $1,2,3,8,9$ & $1,2,3,4,5,6,7,8,9$ & $1,2,3,8,9$ \\
3. High cost of risk management & $1,2,3,5,8,9$ & $1,2,3,4,5,6,7,8,9$ & $1,2,3,5,8,9$ \\
4. Lack of top management support & $1,2,3,4,5,6,7,8,9$ & 4 & 4 \\
5. Lack of formal training to employees & $1,2,3,5,6,7,8,9$ & $3,4,5,7,9$ & $3,5,7,9$ \\
6. Cultural difference & $1,2,3,6,7,8,9$ & $4,5,6,9$ & 6,9 \\
7. Lack of cooperation between employee and top management & $1,2,3,5,7,8,9$ & $1,4,5,6,7,8,9$ & $1,5,7,8,9$ \\
8. Cross-functional conflicts & $1,2,3,7,8,9$ & $1,2,3,4,5,6,7,8,9$ & $1,2,3,7,8,9$ \\
9. Lack of resources & $1,2,3,5,6,7,8,9$ & $2,3,4,5,6,7,8,9$ & $2,3,5,6,7,8,9$ \\
\hline
\end{tabular}


Table 8 Level partition-Iteration III

\begin{tabular}{|c|c|c|c|c|}
\hline Barriers & Reachability set & Antecedent set & Intersection set & level \\
\hline 1. Inertia of employees & $1,2,7$ & $1,2,4,5,6,7,9$ & $1,2,7$ & III \\
\hline 2. Avoidance of talking about risk & $1,2,9$ & $1,2,4,5,6,7,9$ & $1,2,9$ & III \\
\hline 4. Lack of top management support & $1,2,4,5,6,7,9$ & 4 & 4 & \\
\hline 5. Lack of formal training to employees & $1,2,5,6,7,9$ & $4,5,7,9$ & $5,7,9$ & \\
\hline 6. Cultural difference & $1,2,6,7,9,10$ & $4,5,6,9$ & 6,9 & \\
\hline 7. Lack of cooperation between employee and top management & $1,2,5,7,9$ & $1,4,5,6,7,9$ & $1,5,7,9$ & \\
\hline 9. Lack of resources & $1,2,5,6,7,9$ & $2,4,5,6,7,9$ & $2,5,6,7,9$ & \\
\hline
\end{tabular}

Table 9 Level partition-Iteration IV

\begin{tabular}{llll}
\hline Barriers & Reachability set & Antecedent set & Intersection set \\
\hline 4. Lack of top management support & $4,5,6,7,9$ & 4 & 4 \\
5. Lack of formal training to employees & $5,6,7,9$ & $4,5,7,9$ & $5,7,9$ \\
6. Cultural difference & $6,7,9$ & $4,5,6,9$ & 6,9 \\
7. Lack of cooperation between employee and top management & $5,7,9$ & $4,5,6,7,9$ & $5,7,9$ \\
9. Lack of resources & $5,6,7,9$ & $4,5,6,7,9$ & $5,6,7,9$ \\
\hline
\end{tabular}

Table 10 Level partition-Iteration V

\begin{tabular}{|c|c|c|c|c|}
\hline Barriers & Reachability set & Antecedent set & Intersection set & level \\
\hline 4. Lack of top management support & $4,5,6,7$ & 4 & 4 & \\
\hline 5. Lack of formal training to employees & $5,6,7$ & $4,5,7$ & 5,7 & \\
\hline 6. Cultural difference & 6,7 & $4,5,6$ & 6 & \\
\hline 7. Lack of cooperation between employee and top management & 5,7 & $4,5,6,7$ & 5,7 & V \\
\hline
\end{tabular}

Table 11 Level partitionIteration VI

Table 12 Level partitionIteration VII

Table 13 Level partitionIteration VIII

\begin{tabular}{lllll}
\hline Barriers & Reachability set & Antecedent set & Intersection set & level \\
\hline 1. Lack of top management support & $4,5,6$ & 4 & 4 & \\
2. Lack of formal training to employees & 5,6 & 4,5 & 5 & \\
3. Cultural difference & 6 & $4,5,6$ & 6 & VI \\
\hline
\end{tabular}

\begin{tabular}{lllll}
\hline Barriers & Reachability set & Antecedent set & Intersection set & level \\
\hline 1. Lack of top management support & 4,5 & 4 & 4 & \\
2. Lack of formal training to employees & 5 & 4,5 & 5 & VII \\
\hline
\end{tabular}

\begin{tabular}{lllll}
\hline Barriers & Reachability set & Antecedent set & Intersection set & level \\
\hline 1. Lack of top management support & 4 & 4 & 4 & VIII \\
\hline
\end{tabular}

The second iteration is carried out for nine barriers. The tenth barrier selected at the top level in the first iteration is excluded. The second iteration shows that the third and eighth barriers have their intersection sets and reachability sets as identical and contain a maximum number of common barriers. Hence, the barriers "high cost of risk management" and "cross-functional team" are selected at the second level (ref. Table 7).

The third iteration is carried out for seven barriers. The three barriers selected in the first and second iterations are 
excluded. The third iteration shows that the first and second barriers have their intersection sets and reachability sets as identical. Hence, the barriers "inertia of employees" and "avoidance of talking about risks" are selected at the third level (ref. Table 8).

The fourth iteration is carried out for five barriers. The five barriers selected in the initial three iterations are excluded. The fourth iteration shows that the ninth barrier has intersection set and reachability set as identical and contains a maximum number of common barriers. Hence, the barrier "Lack of resources" is selected at the fourth level (ref. Table 9).

The fifth iteration is carried out for four barriers. The six barriers selected in the initial four iterations are excluded. The fifth iteration shows that the seventh barrier has intersection set and reachability set as identical. Hence, the barrier "lack of cooperation between employee and top management" is selected at the fifth level (ref. Table 10).

The sixth iteration is carried out for three barriers. The seven barriers selected in the initial five iterations are excluded. The sixth iteration shows that the sixth barrier has intersection set and reachability set as identical. Hence, the barrier "cultural difference" is selected at the sixth level (ref. Table 11).

The seventh iteration is carried out for two barriers. The eight barriers selected in the initial six iterations are excluded. The seventh iteration shows that the fifth barrier has intersection set and reachability set as identical. Hence, the barrier "lack of formal training to employees" is selected at the seventh level (ref. Table 12).
The eighth iteration is carried out for the last one remaining barrier. The nine barriers selected in the initial seven iterations are excluded. The eighth iteration shows that the fourth barrier has intersection set and reachability set as identical. Hence, the barrier "lack of top management support" is selected at the lowermost eighth level (ref. Table 13).

Table 14 represents the summary of all eight iterations which divides the ten barriers into eight different levels.

\section{Development of diagraph}

After removing transitivity, a final diagraph is prepared. The top-level barrier, i.e., failure to clearly define the risk, is placed at the top of diagraph and the second-level barriers at the second position and so on, until the bottom-level barrier, i.e., lack of top management support, is placed at the lowest position in the diagraph, as shown in Fig. 3.

From left to right, the power to influence other barriers decreases, whereas from right to left, the tendency to get influenced by other barriers increases. Thus, barrier 4 is the most influencing, whereas barrier 10 has the highest influence from other barriers.

\section{Development of ISM-based model}

In the next step, the diagraph is converted into an ISMbased model by replacing nodes of barriers of risk management with statements, as shown in Fig. 4. From the model developed with the identified barriers, it is clear that

Table 14 Summary of iterations for level partitions

\begin{tabular}{|c|c|c|c|c|c|}
\hline Iteration no. & Barrier & Reachability set & Antecedent set & Intersection set & level \\
\hline 1 & 10. Failure to clearly define the risk & $1,2,3,5,7,8,9,10$ & $1,2,3,4,5,6,7,8,9,10$ & $1,2,3,5,7,8,9,10$ & I \\
\hline \multirow[t]{2}{*}{2} & 3. High cost of risk management & $1,2,3,5,8,9$ & $1,2,3,4,5,6,7,8,9$ & $1,2,3,5,8,9$ & II \\
\hline & 8. Cross-functional conflicts & $1,2,3,7,8,9$ & $1,2,3,4,5,6,7,8,9$ & $1,2,3,7,8,9$ & II \\
\hline \multirow[t]{2}{*}{3} & 1. Inertia of employees & $1,2,7$ & $1,2,4,5,6,7,9$ & $1,2,7$ & III \\
\hline & 2. Avoidance of talking about risk & $1,2,9$ & $1,2,4,5,6,7,9$ & $1,2,9$ & III \\
\hline 4 & 9. Lack of resources & $5,6,7,9$ & $4,5,6,7,9$ & $5,6,7,9$ & IV \\
\hline 5 & 7. Lack of cooperation between employee and top management & 5,7 & $4,5,6,7$ & 5,7 & $\mathrm{~V}$ \\
\hline 6 & 6. Cultural difference & 6 & $4,5,6$ & 6 & VI \\
\hline 7 & 5. Lack of formal training to employees & 5 & 4,5 & 5 & VII \\
\hline 8 & 4. Lack of top management support & 4 & 4 & 4 & VIII \\
\hline
\end{tabular}

Fig. 3 Diagraph for barriers in project risk management

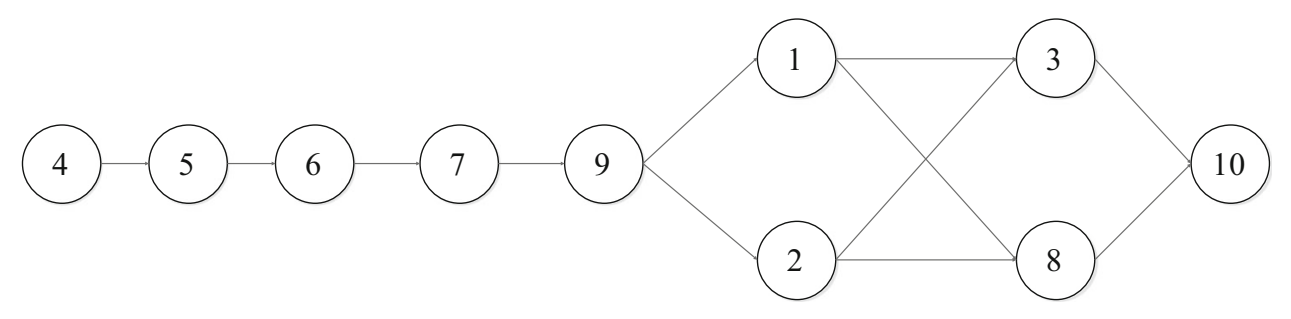


Fig. 4 Model based on ISM technique

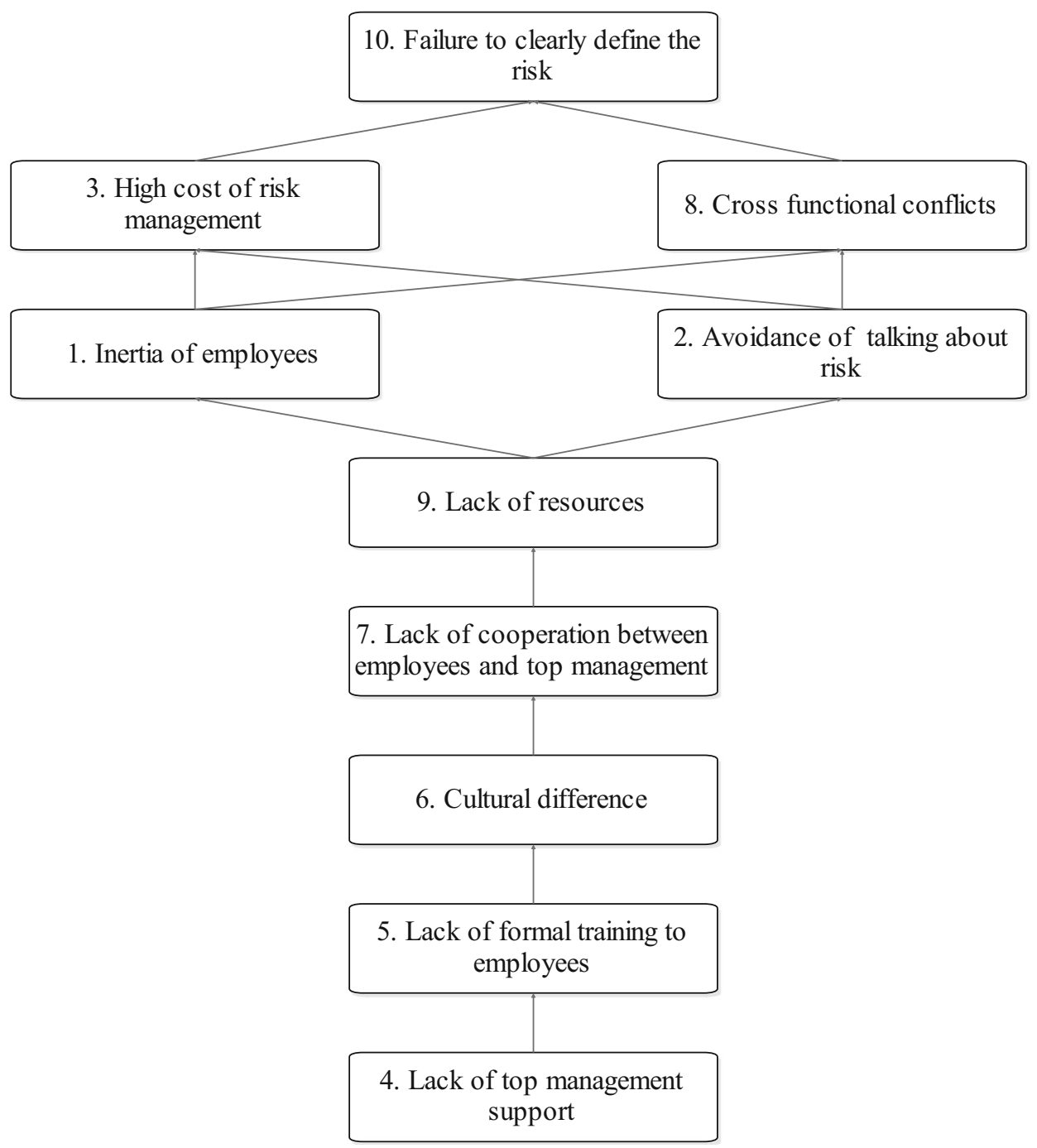

the most important barrier that enable successful implementation of project risk management is lack of top management support which forms the base of ISM hierarchy, whereas barrier like failure to clearly define the risk which is dependent on other barriers has appeared at the top of the hierarchy.

\section{MICMAC analysis}

After obtaining the ISM model for the risk management barriers, the cross-impact matrix multiplication applied to classification abbreviated as MICMAC analysis is applied to prioritize the barriers based on their driving power and dependence. The MICMAC principle is based on multiplication properties of matrices (Mudgal et al. 2010; Sharma et al. 1995; Jadhav et al. 2014a). The objective of MICMAC analysis is to analyse driving power and dependence of the variables (Faisal et al. 2006; Mandal and Deshmukh 1994; Jadhav et al. 2014a). Higher driving power indicates that the barrier highly influences other barriers. Higher dependence indicates that the barrier is highly influenced by other barriers. In the MICMAC analysis, four clusters, namely, autonomous, dependant, linkage, and independent, are represented at the four corners of the square. The horizontal axis represents dependence and the vertical axis represents driving power.

As shown in Fig. 5, each barrier is represented by its number and located in the cell corresponding to its driving power and dependence, as calculated in Table 5. As an illustration, the barrier like lack of top management support has dependence value as 01 and driving power of 10 . Hence, it is located in independent barriers cluster, as shown in Fig. 5.

In this analysis, the project risk management barriers which are described earlier have been classified into four clusters.

Cluster 1(Autonomous risk management barriers): These barriers are relatively disconnected from the system with very few weak links. 


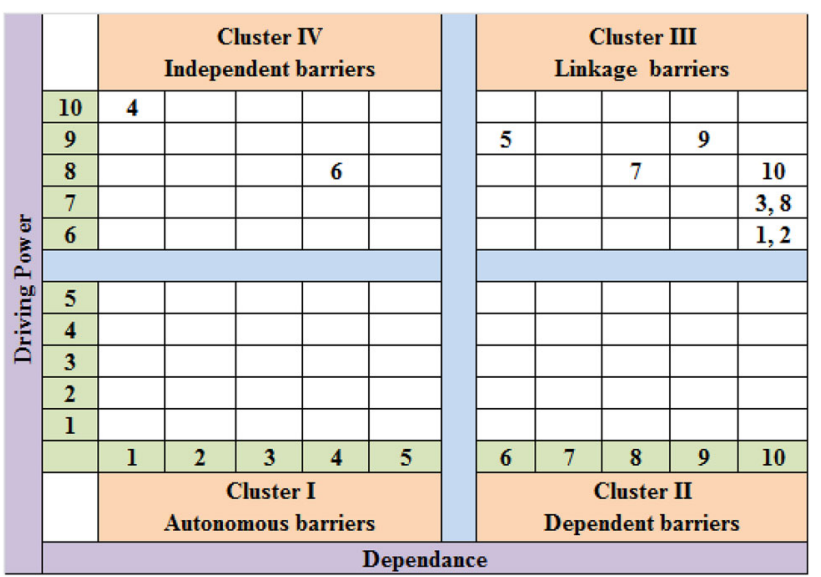

Fig. 5 Model based on MICMAC analysis

Cluster 2(Dependent risk management barriers): These barriers are automatic followers of other barriers.

Cluster 3(Linkage risk management barriers): These barriers are unstable, because any action on these will have an effect on others and also a feedback on themselves.

Cluster 4(Independent risk management barriers): These barriers are the key drivers for implementation. Management has to pay maximum attention to get quick and sustainable results.

Clusters in MICMAC analysis diagram and their characteristics are depicted in Table 15.

\section{Results and discussions}

The practitioners in the field of project risk management must always take into account various possible barriers that can affect adversely their efforts to manage the risks. Understanding the barriers and their interactions among each other is of utmost importance in the project risk management. The ISM methodology combined with MICMAC analysis provided a model as well as dependence and driving power diagram of barriers to project risk management. The interactions among barriers are clearly visible through the ISM model developed. The ISM model indicates that barriers like lack of top management support, lack of formal training, and cultural difference are the top priority barriers which have an effect on other barriers. Hence, more attention should be given to minimize the occurrence of these barriers. The driving power-dependence diagram provides valuable insight about the relative importance of the barriers. The MICMAC analysis concludes that barriers like lack of top management support and cultural difference which appear in the fourth quadrant are the key barriers and management has to pay attention to get quick and sustainable results. Since effective risk management is a crucial part of any project, barriers must be identified at the early stage and prioritized according to their severity. Preparing an action plan to remove the high priority barriers will be the key to effective implementation of risk management which will lead to a successful project.

\section{Strategies to overcome the barriers in risk management of projects}

The following strategies are suggested in consultation with more than 20 project practitioners to overcome the common barriers to project risk management.

Strategy 1: There must be clarity in the mission and goals of the project. The cost and time estimates of the project must be realistic. A clear communication with all stakeholders to gain their buy-into project scope and project management plan is essential to avoid scope creep.

Strategy 2: Risk management must be integrated into the organizational culture and concept of risk responsibility must be promoted. Risks should be prioritized and action
Table 15 Cluster characteristics

\begin{tabular}{lllll}
\hline $\begin{array}{l}\text { No. } \\
\text { title }\end{array}$ & Driving power & Dependence & Risk management barrier \\
\hline I & Autonomous & Weak & Weak & - \\
II & Dependent & Weak & Strong & - \\
III & Linkage & Strong & Weak & 1. Inertia of employees \\
& & & 2. Avoidance of talking about risk \\
& & & 3. High cost of risk management \\
& & & 5. Lack of formal training to employees \\
& & & 7. Lack of cooperation \\
& & & 8. Cross-functional conflicts \\
& & & 9. Lack of resources \\
& & Strong & 10. Failure to clearly define the risk \\
& & & 4. Lack of top management support \\
& & & 6. Cultural difference
\end{tabular}


plan for individual risk response must be prepared and standardized.

Strategy 3: Risk identification must be started at an early stage even before the design starts. Some rewards and incentives can be offered for identifying crucial risks in the project. This will lead to active involvement of employees in risk management implementation.

Strategy 4: Top management must offer a commitment to risk management efforts. They should set up risk management teams, regularly revise risk management plans, allocate risk management responsibilities, listen to problems and suggestions from employees, and arrange for appropriate resources as and when required.

Strategy 5: Employees must be formally trained to create awareness regarding risk management efforts. The training should focus on the importance of risk management in projects; a systematic methodology to identify, clearly define, and prioritize risks related to the specific project; and need and benefits of working in cross-functional teams and optimum utilisation of the available resources.

Strategy 6: Project team members must put emphasis on effective communication within and outside the organization. Communication provides opportunities for clarification, for members to discuss improvement to an organization and impact of using different risk mitigation strategies.

Strategy 7: Top management must ensure effective use of information technology throughout project life cycle as it enables easy access and retrieval of risk data, prompt searches, effective communication, and sharing information about risk identification and response strategies. Information technology also supports top management in controlling project.

Strategy 8: An organizational culture supported by cross-functional teamwork, collaboration, and open communication must be developed within project organization. It will encourage the team members to work more efficiently and effectively. Organizational culture must support trust and cooperation among the team members. This will improve risk management in the project.

Strategy 9: A risk management organizational structure must be established to indicate formal lines of authority and communication and the information and data that flow through these lines.

Strategy 10: High cost involved in risk management efforts must be viewed in a manner, such that it is an investment to prevent the forthcoming losses on account of the occurrence of certain risks in the project. The cost benefit analysis of risk management should be carried out and budget for the risk management implementation should be incorporated into the overall project budget during initial stage only.

\section{Conclusion and remarks-}

\section{Conclusion}

This paper represents the general scenario of the 17 th various risk categories involved in any project and ten barriers associated with effective project risk management. It also attempts to identify possible causes of each risk category which may lead to failure of the project. The paper describes interaction among barriers which will be helpful for further studies in the area of effective implementation of risk management.

The barriers not only affect effective implementation of risk management in projects but also affect one another. The interaction of barriers amongst themselves had been analysed by developing a model using interpretive structural modelling (ISM). The model indicates that barriers like lack of top management support lead to other barriers. A thorough understanding of such barriers can be very helpful to management to effectively implement risk management. It can guide top management to tackle the barriers effectively. MICMAC analysis categorizes barriers into four clusters and emphasizes the need to concentrate more on the barriers which belong to the independent cluster.

The barriers to risk management if identified initially can be of great help to the company to plan for strategies to overcome them. For successful implementation of risk management in any project, risk management team must define risks clearly and proactively address risks consistently throughout the project. Barriers to risk management must be identified at the initial stage, assessed for their probability of occurrence and then responded.

\section{Limitations and future directions}

The primary focus of the study is on risk management in projects in various sectors such as construction engineering, piping engineering, power generation plants, mining, automotive industries, steel industries, and other heavy industries. According to the type of project, barriers to the risk management implementation and strategies to overcome them may vary. The authors have attempted to develop a generic model for barriers to risk management and hence can be used as a basis for risk management planning in any project. The study failed to consider service sector project management, which could open up new dimensions to risk management. In addition, the list of journals considered for the study can be increased to include more diversified risk management practices.

The interaction among barriers can also be analysed using a modelling technique like analytic network process 
(ANP). The model obtained using ANP can be compared with model obtained through ISM technique and a hybrid model can be formed which can be validated using structural equation modelling (SEM). A meta-analysis considering a larger pool of sectors and journals can explore new categories of barriers and investigate the relationship and effect of those new barriers on these existing barriers. Research work in this area may act as a roadmap for effective implementation of risk management in projects and will help the risk management practitioners and researchers.

Acknowledgements The authors wish to thank all the project risk management practitioners and experts who helped in developing the structural self-interaction matrix, which is the foundation of this research work and verifying logical consistencies of the ISM model developed with project risk management philosophy.

Open Access This article is distributed under the terms of the Creative Commons Attribution 4.0 International License (http://crea tivecommons.org/licenses/by/4.0/), which permits unrestricted use, distribution, and reproduction in any medium, provided you give appropriate credit to the original author(s) and the source, provide a link to the Creative Commons license, and indicate if changes were made.

\section{References}

Ahsan K, Gunawan I (2010) Analysis of cost and schedule performance of international development projects. Int J Proj Manage 28:68-78

Alawamleh M, Popplewell K (2011) Interpretive structural modelling of risk sources in a virtual organisation. Int $\mathrm{J}$ Prod Res 49(20):6041-6063

Allen M, Carpenter C, Hutchins M, Jones G (2015) Impact of risk management on project cost: an industry comparison. J Inf Technol Econ Dev 6(2):1

Aloini D, Dulmin R, Mininno V (2012) Modelling and assessing ERP project risks, a Petri net approach. Eur J Oper Res 220:484-495

Anderson SW (2000) 'Identifying and managing risk in international mining projects. In: Paper presented at the National Western Mining Conference, November, 2000

Attri R, Nikhil Dev N, Sharma V (2013) Interpretive structural modelling (ISM) approach: an overview. Res J Manag Sci 2(2):3-8

Aven T (2016) Risk assessment and risk management: review of recent advances on their foundation. Eur J Oper Res 253:1-13

Barber R (2005) Understanding internally generated risks in projects. Int J Proj Manag 23:584-590

Bhoola V, Hiremath SB, Mallik D (2014) An assessment of risk response strategies practiced in software projects. Australas J Inf Syst 18(3):161-191

Bing L, Akintoye A, Akintoye PJ, Edwards PJ, Hardcastle C (2005) The allocation of risk in PPP/PFI construction projects in the UK. Int J Proj Manag 23:25-35

Boateng P, Chen Z, Ogunlana SO (2015) An analytical network process model for risks prioritisation in megaprojects. Int J Proj Manag 33:1795-1811

Bush JK, Dai WS, Dieck GS, Hostelley LS, Hassall T (2005) The art and science of risk management-a US research based industry perspective. Drug Saf 28(1):1-18
Camprieu R (2007) Cultural differences in project risk perception: An empirical comparison of China and Canada. Int J Proj Manag 25:683-693

Carr V, Tah JHM (2001) A fuzzy approach to construction project risk assessment and analysis: construction project risk management system. Adv Eng Softw 32:847-857

Charan P, Shankar R, Baisya RK (2008) Analysis of Interactions among variables of supply chain performance measurement system implementation. Business Process Manag J 14(4):512-529

Charoenngam C, Yeh CY (1999) Contractual risk and liability sharing in hydropower construction. Int J Proj Manag 17(1):29-37

Doloi H, Anil Sawhney KC, Iyer Sameer Rentala (2012) Analysing factors affecting delays in Indian construction projects. Int J Proj Manag 30:479-489

Elkington P, Smallman C (2002) Managing project risks: a case study from the utility sector. Int J Proj Manag 20:49-57

Eswarlal VK, Dey PK, Budhwar P, Shankar R (2011) Analysis of interactions among variables of renewable energy projects-A case study on renewable energy projects in India. J Sci Ind Res 70:713-720

Eybpoosh M, Dikmen I, Talat Birgonul M (2011) Identification of risk paths in international construction projects using structural equation modelling. J Constr Eng Manag 137(12):1164-1175

Faisal MN (2010) Analysing the barriers to corporate social responsibility in supply chains: an interpretive structural modelling approach. Int J Logist Res Appl 13(3):179-195

Faisal MN, Banwet DK, Shankar R (2006) Supply chain risk mitigation: modelling the enablers. Business Process Manag $\mathrm{J}$ 12(4):535-552

Fan M, Lin NP, Sheu C (2008) Choosing a project risk handling strategy- An analytical model. Int J Prod Econ 112:700-713

Fang C, Marle F (2012) A simulation based risk network model for decision support in project risk management. Decis Support Syst 52:635-644

Farr-Wharton R (2003) Multimedia projects and the optimum choice of individuals and teams. Int J Proj Manag 21(4):271-280

George J, Pramod VR (2014) An ISM analysis approach in still rerolling mills. Int J Res Eng Technol 2(4):161-174

Ghosh S, Jintanapakanont J (2004) Identifying and assessing the critical risk factors in an underground rail project in Thailand: a factor analysis approach. Int J Proj Manag 22:633-643

Grant KP, Cashman WM, Christensen DS (2006) Delivering projects on time. Res Technol Manag 49:52-58

Grey C, Larson E, Desai G (2010) 'Project management-the managerial process, 4th edn. McGraw-Hill, New York, pp 615-638

Gupta J, Sravat A (1998) Development and project financing of private power projects in developing countries: a case study of India. Int J Proj Manag 16(2):99-105

Han S, Kim DY, Kim H, Jang WS (2008) A web-based integrated system for international project risk management. Autom Constr 17:342-356

Hanna AS, Ibrahim MW, Lotfallah W, Iskandar KA, Russell JS (2016) Modeling project manager competency: an integrated mathematical approach. J Constr Eng Manag 142(8):04016029

Harner MM (2010) Barriers to effective risk management. Seton Hall Law Review 40(4):1323-1365

Hartono B, Sulistyo SR, Praftiwi PP, Hasmoro D (2013) Project risk: theoretical concepts and stakeholders' perspectives. Int J Proj Manag. doi:10.1016/j.ijproman.2013.05.011

Huo X, Zhang L, Guo H (2016) Antecedents of relationship conflict in cross-functional project teams. Proj Manag J 47(5):52-69

Hwang BG, Zhao X, Gay MJS (2013) Public-private partnership projects in Singapore: factors, critical risks, and preferred risk 
allocation from the perspective of contractors. Int J Proj Manag 31:424-433

Hwang BG, Zhao X, Toh LP (2014) Risk management in small construction projects in Singapore: status, barriers and impact. Int J Proj Manag 32:116-124

Isaac I (1995) Training in risk management. Int J Proj Manag 13:225-229

Jadhav J, Mantha S, Rane S (2014a) Development of framework for sustainable Lean implementation: an ISM approach. J Ind Eng Int 10:72

Jadhav J, Mantha S, Rane S (2014b) Barriers for successful implementation of JIT-a manufacturers perspective. Int $\mathrm{J}$ Procure Manag 7(3):316-342

Jadhav J, Mantha S, Rane S (2015a) Roadmap for Lean implementation in Indian automotive component manufacturing industry: comparative study of UNIDO Model and ISM Model. J Ind Eng Int 11(2):179-198

Jadhav J, Mantha S, Rane S (2015b) Analysis of interactions among the barriers to JIT production: interpretive structural modelling approach. J Ind Eng Int 11:331-352

Jamil M, Mufti NA, Khan AH (2008) Risk identification for international joint venture construction projects. In: Paper presented at first international conference on construction in developing Countries (ICCIDC-I), 4-5 August 2008, Karachi, Pakistan

Jannadi OA, Almishari S (2003) Risk assessment in construction. J Constr Eng Manag 129:492

Kannan G, Haq AN, Sasikumar P, Arunachalam S (2008) Analysis and selection of green suppliers using interpretative structural modelling and analytic hierarchy process. Int $\mathbf{J}$ Manag Decis Making 9(2):163-182

Ke Y, Wang SQ, Chan APC, Lam PTI (2010) Preferred risk allocation in China's public-private partnership (PPP) projects. Int J Proj Manag 28:482-492

Keizer JA, Halman JIM, Song M (2002) From experience-applying the risk diagnosing methodology. J Prod Innov Manag 19(3):213-232

Khattab AL, Anchor JR, Davies EMM (2007) Managerial perceptions of political risk in international projects. Int $\mathrm{J}$ Proj Manag 25(7):734-743

Kirkire MS, Rane SB, Jadhav JR (2015) 'Risk management in medical product development process using traditional FMEA and fuzzy linguistic approach: a case study. J Ind Eng Int 11(4):595-611

Kumar N, Kumar S, Haleem A, Gahlot P (2013a) implementing lean manufacturing system: ISM approach. J Ind Eng Manag 6(4):996-1012

Kumar S, Luthra S, Haleem A (2013b) Customer involvement in greening the supply chain: an interpretive structural modelling methodology. J Ind Eng Int 9(6):1-13

Kutsch E, Hall M (2010) Deliberate ignorance in project risk management. Int J Proj Manag 28(3):245-255

Lam KC, Wang D, Lee Patricia TK, Tsang YT (2007) Modelling risk allocation decision in construction contracts. Int J Proj Manag 25:485-493

Latham M (1994) Constructing the team. HMSO, London

Lee E, Park Y, Shin JG (2009) Large engineering project risk management using a Bayesian belief network. Expert Syst Appl $36: 5880-5887$

Li S (2009) Risk management for overseas development projects. Int Business Res 2(3):193-196

Ling FYY, Hoi L (2006) Risks faced by Singapore firms when undertaking construction projects in India. Int $\mathbf{J}$ Proj Manag 24:261-270
Liu GH, Wang E, Chua CEH (2015) leveraging social capital to obtain top management support in complex, cross-functional it projects. J Assoc Inf Syst 16(8):707

Lundy V, Morin PP (2013) Project leadership influences resistance to change: the case of the Canadian public service. Proj Manag J 44(4):45-64

Mandal A, Deshmukh SG (1994) Vendor selection using interpretive structural modelling. Int J Oper Prod Manag 14(6):52-59

Marle F, Vidal L (2011) Project risk management processes: improving coordination using a clustering approach. Res Eng Design 22:189-206

Miller R, Lessard D (2001) Understanding and managing risks in large engineering projects. Int J Project Manag 19(8):437-443

Moed HF (2010) 'The Source-Normalized Impact per Paper (SNIP) is a valid and sophisticated indicator of journal citation impact.' arXiv preprint arXiv, p. 1005.4906

Mudgal RK, Shankar R, Talib P, Raj T (2010) Modelling the barriers of green supply chain practices: an Indian perspective. Int $\mathrm{J}$ Logist Syst Manag 7(1):81-107

Murray S, Grantham K, Damle S (2011) Development of a generic risk matrix to manage project risks. J Ind Syst Eng 5(1):35-51

Palm K, Lindahl M (2015) A project as a workplace: observations from project managers in four $\mathrm{R} \& \mathrm{D}$ and project-intensive companies. Int J Proj Manag 33:828-838

Patterson FD, Neailey K (2002) A risk register database system to aid the management of project risk. Int J Proj Manag 20:365-374

PMI (2013) A guide to the Project Management Body of Knowledge (PMBOK Guide), 5th edn. Project Management Institute, Newtown Square, Pennsylvania. ISBN: 978-1-935589-67-9

Raj T, Shankar R, Suhaib M (2010) An ISM approach for modelling the enablers of Flexible manufacturing system: the case for India. Int J Prod Res 46(24):6883-6912

Rajesh KS, Suresh KG, Deshmukh SG (2007) Interpretive structural modelling of factors for improving competitiveness of SMEs. Int J Prod Qual Manag 2(4):423-440

Ravi V, Shankar R (2005) Analysis of interactions among the barriers of reverse logistics. Technol Forecast Soc Chang 72(8):1011-1029

Raz T, Michael E (2001) Use and benefits of tools for project risk management. Int J Proj Manag 24:261-270

Sarewitz D, PielkeJr R, Keykhah M (2003) Vulnerability and risk: some thoughts from a political and policy perspective. Risk Anal 23(4):805-810

Sato T, Hirao M (2013) Optimum budget allocation method for projects with critical risks. Int J Proj Manag 31:126-135

Sennara M and Hartman F (2002) Managing Cultural Risks on International Projects. In: Paper presented at the project management institute annual seminars and symposium, 3-10 October 2002, San Antonio, Texas, USA

Shahabadkar P, Hebbal SS, Prashant S (2012) Deployment of interpretive structural modelling methodology in supply chain management-an overview. Int $J$ Ind Eng Prod Res 23(3):195-205

Sharma HD, Gupta AD, Sushil (1995) The objectives of waste management in India: a future inquiry. Technol Forecast Soc Change 48(3):285-309

Smith PG, Merritt GM (2002) Proactive risk management: controlling uncertainty in product development. Productivity Press, New York

Solanki KL, Choudhary AKS (2014) Categorising Productivity issues using ISM. Int J Res Aeronaut Mech Eng 2(6):96-105

Stewart R, Fortune J (1995) Application of systems thinking to the identification, avoidance, and prevention of risk. Int $\mathrm{J}$ Proj Manag 19:9-17 
Tah JHM, Carr V (2001) Knowledge-based approach to construction project risk management. J Comput in Civil Eng ASCE 15(3): 170-177

Thakkar J, Kanda A, Deshmukh SG (2008) Evaluation of buyersupplier relationships using an integrated mathematical approach of interpretive structural modelling (ISM) and graph theoretic approach. J Manuf Technol Manag 19(1):92-124

The Standish Group Report (2013) CHAOS, http://www.stan dishgroup.com/chaos.html. Accessed 04 July 2015

Titarenko BP (1997) Robust Technology in risk management. Int J Proj Manag 15(1):11-14

Tummala VR, Leung HM, Mok CK, Burchett JF, Leung YH (1997) Practices, benefits and barriers of using risk management approaches in selected Hongkong Industries. Int J Proj Manag 15(5):297-312

Turner JR, Ledwith A, Kelly J (2010) Project Management in small to medium sized enterprises: matching processes to the nature of the firm. Int J Proj Manag 28(8):744-755

Vaisblat BI (2014) 'Optimization of project risk management. Econ Anal Issue 27:14-18
Walewski J, Gibson G (2003) International project risk assessmentmethods, procedures and critical factors. Centre Construction Industry Studies, University of Texas, Austin

Ward S, Chapman C (2003) Transforming project risk management into project uncertainty management. Int $\mathbf{J}$ Proj Manag 21:97-105

Warfield JW (1974) Developing interconnected matrices in structural modelling. IEEE Trans Syst Men Cybern 4(1):81-87

Yazid A, Abdullah A, Hussain M (2014) A review of infrastructure project risk management. Int Business Manag 8(6):342-347

Yim R, C Jason, Doolen T, Tumer I, Malak R (2015) A study of the impact of project classification on project risk indicators. Int $\mathbf{J}$ Proj Manag 33:863-876

Zou PXW, Zhang G, Wang J (2007) Understanding the key risks in construction projects in China. Int J Proj Manag 25:601-614

Zwikael O, Sadeh A (2007) Planning effort as an effective risk management tool. J Oper Manag 25:755-767

Zwikael O, Pathak R, Singh G, Ahmad S (2013) The moderating effect of risk on the relationship between planning and success. Int J Proj Manag. doi:10.1016/j.ijproman.2013.07.002 